\title{
姉妹にみられた血小板無力症患者の抜菌症例
}

\author{
福田道男・細田超・瀬上夏樹・小若純久
}

\section{Tooth extraction in sisters with Glanzmann's thrombasthenia}

\author{
Michio Fukuda - Masaru Hosoda - Natsuki Segami - Sumihisa Kowaka
}

\begin{abstract}
Two sisters suffering from Glanzmann's thrombasthenia required extraction of decayed permanent teeth. This report describes the etiology and diagnosis of thrombasthenia, and reviews the literature concerning tooth extraction, with an cmphasis on hemostatic procedurcs including platelet transfusion and local management.
\end{abstract}

Key words: Glanzmann's thrombasthenia

緒

言

口腔領域においては観血的処笽がしばしば行われてい るが，その中にあって止血困難な症例に造遇することが まれではない，その出血原因の大半が局所的要因である が，時には出血性素因が原因の場合がある。 したがって 病茬，臨床症状などから出血性糸因が疑われた場合には 出血傾向の㭘查が必要であり, その結果適切な管理のも とで観血的処凬が行われなければならない。

出血性素因には血管の障害によるもの，血小板の陪害 によるもの，凝固系の障害によるもの，線維䋕系による ものなどに大別される，その中で血小板の变㕩には，血 小板数の異常のほかに血小板機能の罢常がある．血小板 無力症（thrombasthenia）は代表的な先天性血小板機能


小板形態異常を示す出血性疾患として Glanzmann(1918 年) によより報告された比較的まれな疾患として知られ ている.

今回われわれは血小板無力症患者姉妹の抜隶の 2 症例 を経駗したのでその概要を報告するとともに，血小板無 力症についての若干の文献的考察を加えた。

症

例

症例 1

患 者: 46战 女性:

川崎医科大学口腔外科学教空

（主任：福田道男教授）

Department of Oral Surgery, Kawasaki Medical

School (Chief: Prof. Michio Fukuda)

受付日：炤利59年 5 月 4 日
初 診: 昭和 57 年 9 月

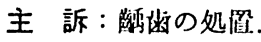

既往歷：生後 4 か月頃より顔而なとに柴亥が出現し， 出血性糸因の指摘をらけている。 その後も波第畤に颜

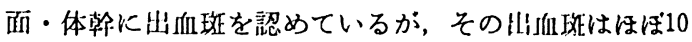
日前後で消失している，大出血などは䋖験していない。



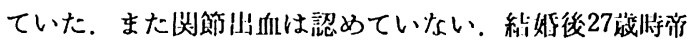
王切開で出痤したか，股部罪常山们をくり返し，約 3 か 月入院加療，血小板輸血をらけている。

家族歴：雨親はいとこはん，いわ刚る血族結婚で，妹 す出血性装因（症例 2）である。 その他の家族には出血 倾向はない（図 1).

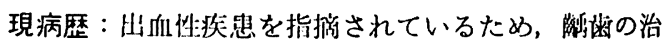
療を受けることは全くなく放卧していた。


図 1 家系肶 


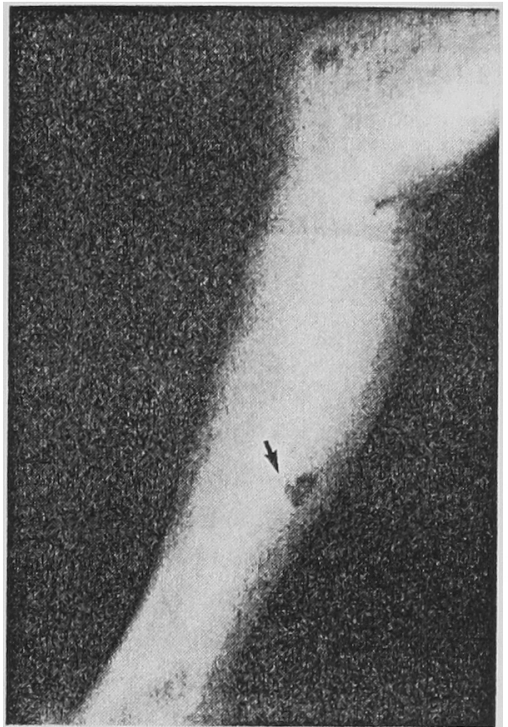

写直 1 下腿の皮下出血斑（症例 I）

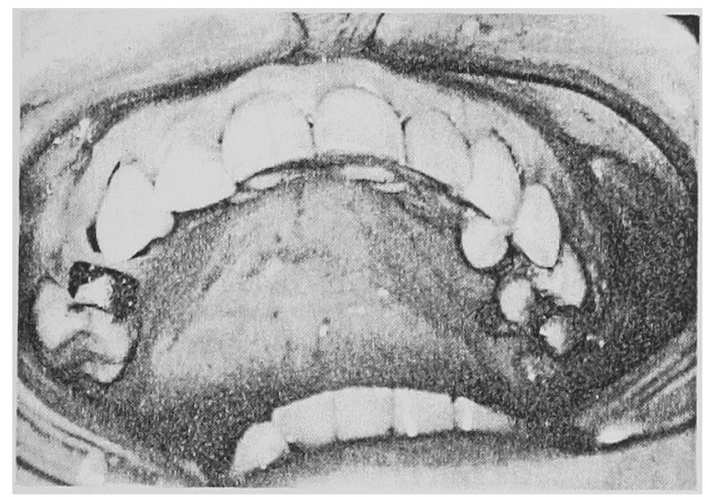

写真 2 初診時の口悾内（症例 1）

\section{現 症}

全身所見：体格，喿䓯ともに良，肝，脾の隀大はな



\section{局所所見}

口腔外所見：颜貌などには出向斑は認めず，またその 他の罪榙もない。



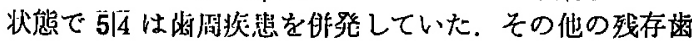



臨床挨查所見：一般血没饮查，血清生化学検盉，冰㢵

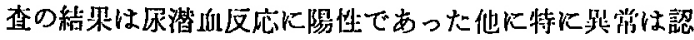
めていない，凝血学的恰查では表 1 のごとく，血小板数 は正常优を示したが，出血洔間は 8 分と延長し，陰压





写直 3 初㟝時のパノラ X線（症侧 1）

Aggeler-Hamlin 法)は29.6\%と低下を示した。また， ガラスビーズへの血小板粘着能も高度の低下を認めた。 血小板凝集能は，図 2 のごとく $10 \mu \mathrm{M}$ の高漉度の ADP (adenosin diphosphate) は欠如し，コラーダン，レス トセチンもともに反応は久如していた，ブロトロンビン 時間（PPT）および，活性化部分トロンボブラスチン時 間（APTT）は正常值を示し，トロンボェラストダラム の ma (maximum amplitude) は軽度の狒小を認めた。

これらの結果は血小板無力症の特徵と一致し，本学血液 内科の站診でる確認された。

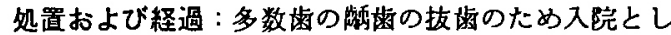
た。あらかしめレジン止血用床副子の作製ならびに浱縮 血小板を準修した，抜歯は 2 回に分割し，10月ロ，11 月ロにそれぞれ $\overline{654|456 ， 54| 67}$ について行った。 桭 醉は $2 \% \mathrm{E}$ キシロカインで通法のごとく局所啲醉を行い

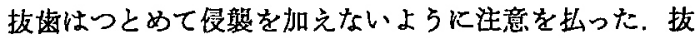
海後はスポンゼルを拆入し，相対する頓・舌または頓・ロ 蓋掬肉縁を释合系によって可及的に引き笴せるようにし た。術中，特に買常出血を認めることなく終了した，術 後る出血はみられず，浩縮血小板，レジン止血用床副子 を使用することなく経過した。また特に止血剂の使用も

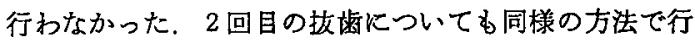
い, やはり濃縮血小板，床副子の使用なしに経過し，抜 歯創の治疼も良好で退院した。

\section{症例 2}

患 者: 41藏 女性

初 診：昭和57年 9 月—.

主 訴：触齿の処置.

既往歷：生後 6 か月頃ネズミに手指を濑をれ長時間出 血し，紫斑病の診断を5けその後も出，皮下出血斑 をくり返し，乳涵脱落時の長時間出血を経験して，虫垂 切除術や分始時には輸血をらけている．また本人は著者 らにより28歳歯科治療時に血小板無力症の確定診断を得

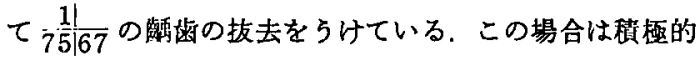
な局所止血処濫のみで輸血などの処值を行らことなく良 好に経過した既往がある2). 
表 1 凝血学的検疋 (症例 1)

\begin{tabular}{|c|c|c|}
\hline 血小板数（值接法） & $23.9 \times 10^{4} / \mu 1$ & $\left(15 \sim 35 \times 10^{1}\right)$ \\
\hline 出血時間（Ivy 法） & 8 分 & $(1 \sim 6)$ \\
\hline 毛細血管抵抗（㓌珐法） & 25 & $\left(\begin{array}{l}200 \mathrm{mmHg} \\
10 \text { 以下 }\end{array}\right)$ \\
\hline 血飭収縮到驗（Lucia-Aggeler 法） & $29.6 \%$ & $(7.9 \pm 6.0)$ \\
\hline \multicolumn{3}{|l|}{ 血小板凝集能 } \\
\hline & & コントロール \\
\hline $\operatorname{ADP}(10 \mu \mathrm{M})$ & 父 如 & $(77 \%)$ \\
\hline コラーゲン $(4 \mathrm{mg} / \mathrm{ml})$ & 欠 如 & $(68 \%)$ \\
\hline リストセチン $(1.0 \mathrm{mg} / \mathrm{ml})$ & 久 如 & $(75 \%)$ \\
\hline 第VII因子凝固活性（VII：C） & $100 \%$ & $(50 \sim 150)$ \\
\hline PPT & 10.8 秒 & $(10.8 \pm 0.6)$ \\
\hline APTT & 22.7 秒 & $(26.3 \pm 2.5)$ \\
\hline \multirow[t]{3}{*}{ Thromboelastograph } & $r: 12$ 分 & $(6.5 \sim 10.5)$ \\
\hline & $k$ : 6 分 & $(5.5 \sim 9)$ \\
\hline & $\mathrm{ma}: 41 \mathrm{~mm}$ & $(50 \sim 63)$ \\
\hline
\end{tabular}
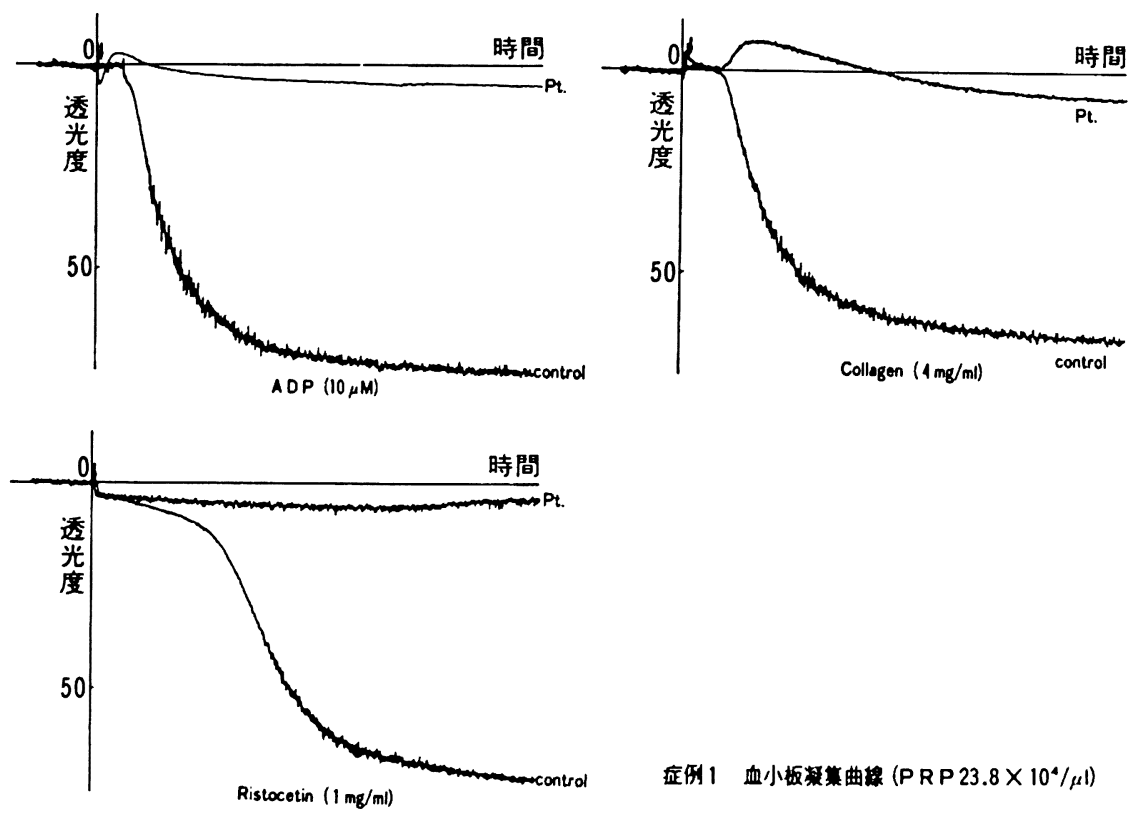

症俐1血小板策曲 $\left(\mathrm{PRP} 23.8 \times 10^{4} / \mu 1\right)$

图 2 血小板凝集能（症例 1)

現病歴：生来の出血㑯向のために 18 についての歯科 治療は行わず放瞃していた，特に疼痛は訴えていない，

現 症

全身所見：体格，栄養ともに良．肝，肺の胛大むな い. 左时頭部に皮下出血斑を悲めている（写直 4 ）。

\section{局所所見}

口腔外所見：顔貌などに出血斑はなく，界常所見も認
めない.



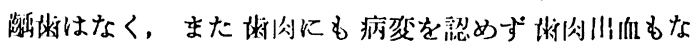
い.


查での罢常は尿潜血反応で际珄，㞗沛淮で赫血球20３0 HPF であった，凝血学的惔查では表 2 のごとく血小板 
表 2 凝血学的梌李（症例 2)

\begin{tabular}{|c|c|c|}
\hline 血小板数（直接法） & $26.2 \times 10^{4} / \mu 1$ & $\left(15 \sim 35 \times 10^{4}\right)$ \\
\hline 出听時间（lvy 法） & 10分以上 & $(1 \sim 6)$ \\
\hline 毛和血管抵抗（陰圧法） & 16 & $\left(\begin{array}{l}200 \mathrm{mmHg} \\
10 \text { 以下 }\end{array}\right)$ \\
\hline 血饵收收縮試挋 (Lucia-Aggeler 法) & $29.3 \%$ & $(7.9 \pm 6.0)$ \\
\hline 血小板粘着能（Salzman 㤎法） & $9.1 \%$ & $(25 \sim 60)$ \\
\hline 血小板智集能 & & コントロール \\
\hline $\operatorname{ADP}(10 \mu \mathrm{M})$ & 父 如 & $(77 \%)$ \\
\hline コラーグン $(4 \mathrm{mg} / \mathrm{ml})$ & 欠 如 & $(68 \%)$ \\
\hline リストセチン $(1.0 \mathrm{mg} / \mathrm{m} l)$ & 欠 如 & $(75 \%)$ \\
\hline 第林因子湝圆活性（VIII：C） & $100 \%$ & $(50 \sim 150)$ \\
\hline PPT & 10.8秒 & $(10.8 \pm 0.6)$ \\
\hline APTT & 22. 6 秒 & $(26.3 \pm 2.5)$ \\
\hline \multirow[t]{2}{*}{ Thromboelastograph } & $r: 14$ 分 & $(6.5 \sim 10.5)$ \\
\hline & $\begin{array}{c}\mathrm{k}: \quad 7 \text { 分 } \\
\mathrm{ma}: 40 \mathrm{~mm}\end{array}$ & $\begin{array}{l}(5.5 \sim 9) \\
(50 \sim 63)\end{array}$ \\
\hline
\end{tabular}
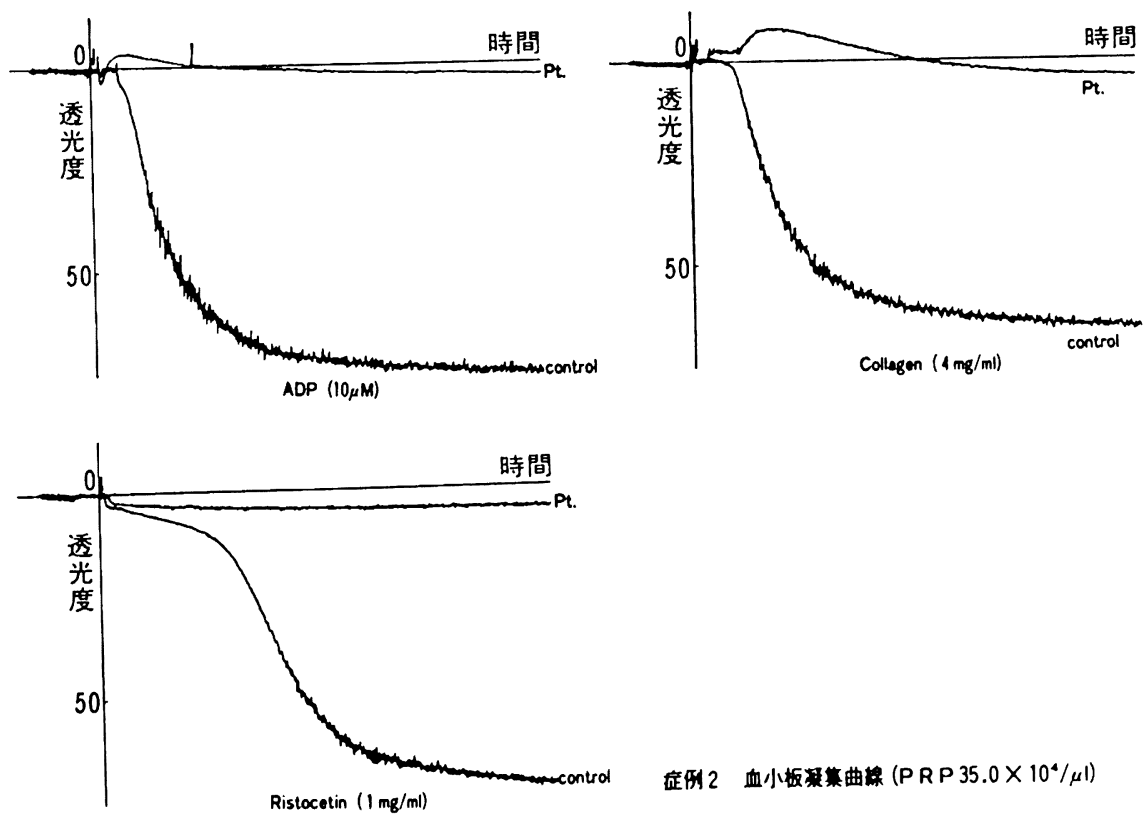

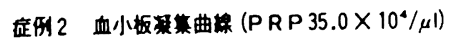

图 3 IIII 小板凝血能（庭侧 2)

数は正営値を示したが，H血洔間は10分以上と著しく迎



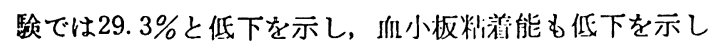

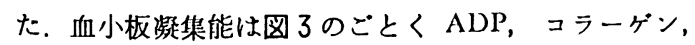
レストセチンのすべて凝集反応は久如していた。 PTT, APTT は正常, トロンボェラストグラムの ma は怪度

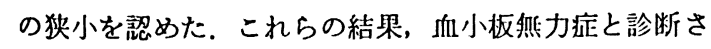

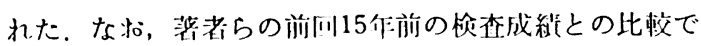
は，梌存才法も多少罪なり比洨することができない顶目

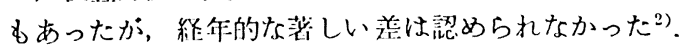

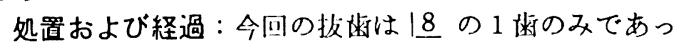
たが、レシンン此血用床测子ならびに滺原血小板を辈满し


$1.0 \mathrm{ml}$ を行い可及的侵裂を加えないよ5に注意を妅い 


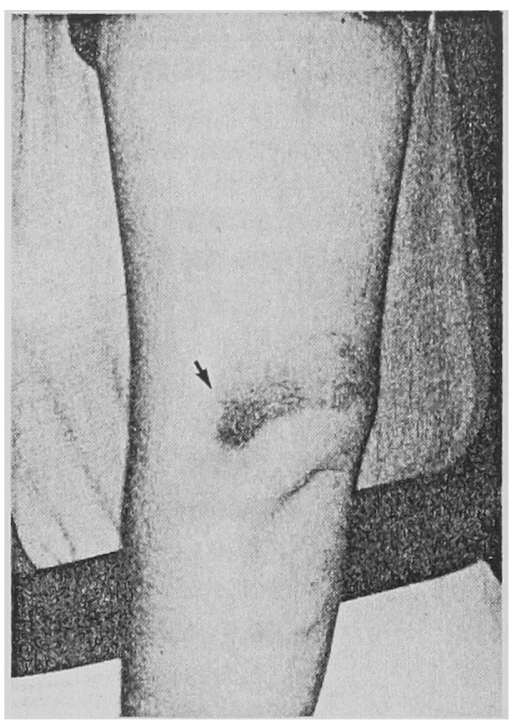

写真 4 左的頭部の皮下出血斑（症例 2）

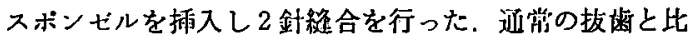

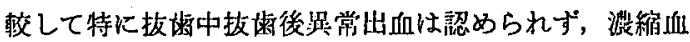
小板の輸注を必要としなかった．找呲後 3 日目に报系を 行い，剣感染もなく良好に経溫し8日目に退院した。

$$
\text { 考察 }
$$

出血倒向についての血小板陪害には，血小板数の娍少 と血小板機能罢背があるが，その中にあって先天性血小

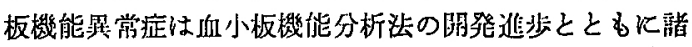


れているが必ずしも確立されていないる゙，最近では血

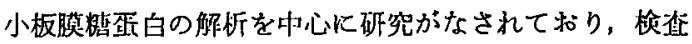

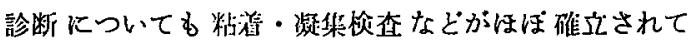


常の分類または血小板の反応機序监常の 分類には表 3



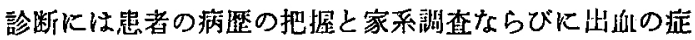
状などを精查の上，出血哇间，血小板数の算定，粘着能， 凝集能，血小板第 3 因子活珄，血䬦収縮などの湘定が必 要となる。

血小板㶵力症 (Wrombocytoasthcnia) は, Glanzmann

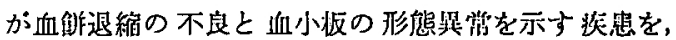
hereditäre hacmorrhagische thrombasthenie として报

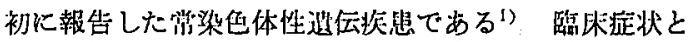

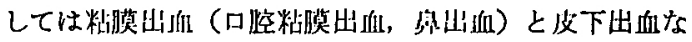
どす起こしやすく，そのほか，向尿，外伤後の止拈因奞 などがみられる。本症例では 2 例とも战膜比向は認めら

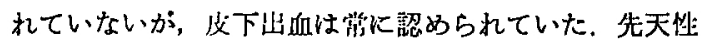

\section{表 3 Ultin の血小板罪党症の分類}
1 thrombasthenia
2 essential athrombia
3 thrombopathic syndrome
a ) Bernard-Soulier syndrome
b ) Collagen inefTectiveness
c) Storage pool disease
d) May-Hegglin disease (anomaly)
e ) Hermansky-Pudlak syndrome

4 others

3) Wiskott-Aldrich syndrome

b) Von Willebrand disease and syndrome

c) Glycogen storage disease

（山田，1974年）ょり引用。

\section{表 4 血小板暴常正の分類（福非）}

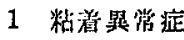

a ) Bernard-Soulier 症候群

b) Von Willebrand 病（外因性血小板機能異学）

c) Ehlers-Danlos 病 (外因性血小板機能是常)

2 放出鼠常遈

a) Storage pool 病

i Hermansky-Pudlak 迹候群

ii Wiskott-Aldrich 症候群

iii Clıcdiak-Higashi 症候群

b ) プロスタグランデン合成恋篦 cyclo-oxygenase 火乏症

c） スクレオチッド合成障䜿

败源病 1 型

果猫-1-6ディフォスフォターゼ欠乏症

$3 \mathrm{ADP}$ 一次凝集欠損症

a ) 拈小板热力症

b) essential athrombia

血小板無力症の定辣は必ずしも碓立されていないが，血

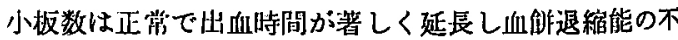
良を諰め，さらに ADP，コラーゲンなどの通常の㠜集 剂による欵集が起をないことが特徽であるとされてい る4. したがって血小板無力症の診断には，臨床症状な



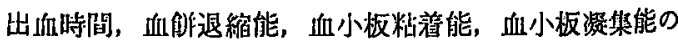
検查が必要である(表 5 無力症の検查) ${ }^{4}$ ，

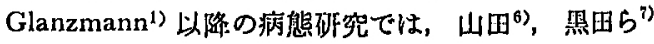

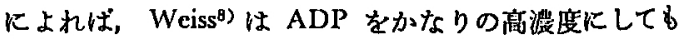
凝集が起こらないことが特徽として血小板無力症を報告 した. Moser ${ }^{0)}$, Karpatkin ${ }^{10)}$ ，桜庭 $5^{11)}$ は glutathione peroxidase の久そが reduced glutathione (GSH) の上 
表 5 先灭性血小板無力症の检查

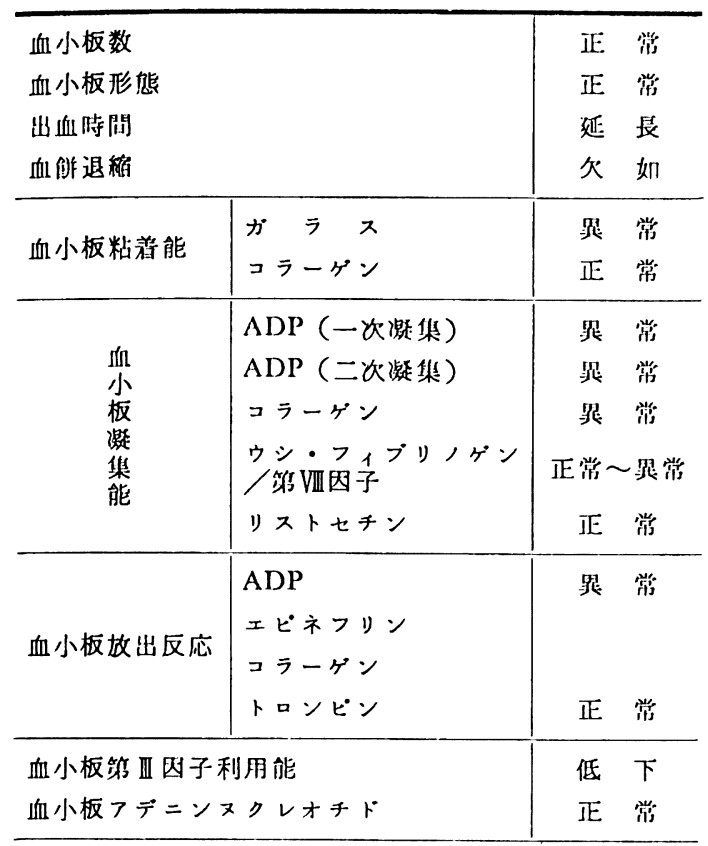

（安永，1983年）より引用


異常が起こるとしている. しかし Beutler ${ }^{12)}$ は reduced GSH 欠乏は溶血については強くなく薬剤誘発によって のみ溶血するため，然力症の場合は著明な出血偄向が起 こると考えてょいかどらか榆討の余地があるとのべてい る. Caen ${ }^{13)}$ や Nachman 5 ${ }^{14)}$ は正常の血小板のフィブ リノーゲンは全フィブリノーゲンの $27 \%$ を占めている が，無力症の場合は全量の10\%にすきずまた質的にも罢 常があると述へててっィ゙リノーゲンに問題があると述べ ている．また血小板の収縮蛋白に重要な関係があるとさ れている thrombosthenin 減少はないと述べているか; Booyse ${ }^{(5)}$ は血小板の表面の thrombosthenin は減少して いると報告している。最近では Nurden ら ${ }^{16)}$, Phillips ${ }^{17)}$, 高桥 $^{(8)}$ ，三上ら ${ }^{(9)}$ は血小板膜糡蛋白の一部に 欠如があ り，ADP 凝集の欠如に大きな影響があると述べてい る.いずれにしても血小板然力症の病態は血小板の ADP 一次凝集の欠如を特徽とする疾患で，血小板数は正常で 血小板形熊も正常であるが，出血犊間は著明に延長し血 作退緶は久如ないしは低下がみられることを本症の診断 上の特改とする．しかし症例が少ないために今後な扮研 究が進んで血小板機能検查の進步により病热病因の究叮] がのぞまれる。

本邦における本症の発生頻度は，初めははなはだまれ であるとされていたが，その後の診断法の進歩ならびに 全国的な実態調査が行われるに従い，1976年では先天性
血小板機倾思常症患者は 162 例が確涩され，そのうち血 小板㷛力症は98例であった ${ }^{20)}$ ．さらに1981作の安永の全

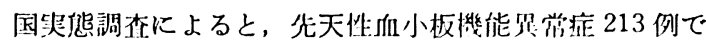

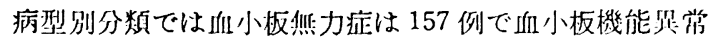
症の中での㑑力症の占める制合は73.7\%ともっとも多く

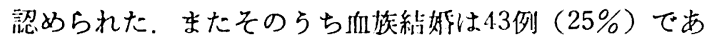
ったと報告している21).

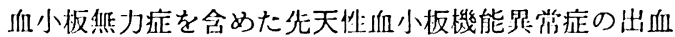
洔の治療むたは手術時出向の予防には一般的には新鲜正

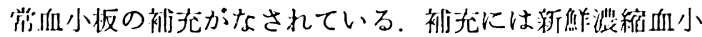
板（PRP）が仙用されるが 1 回の PRP 使用监は10 20 监位が目安とされている゙），無力症のごとき一次凝集異 常症の場合は多显が必要とされて，放出罢范のときは少 盐の补充でよいといわれているが5)，絽り返しの輸拄は 用炎や血小板抗作を鲉生することなどから無計画な輪注 はさけるべきであるとされている，また频问の出血を絽 り返す血小板仳力症の㭃览では血狠型抽よび HLA type の適合した大人の spender を碓保して执いて必要量を連 続成分採向装䍜を使って採取して輸注することが望まし いと述へているら）、腔领域の拔㴹などについての本邦 での止血处活は，われわれの沙伤した箱明では表 6 のご とく12 例が報告されている2,7,22 29). 症例 1 と症例12は

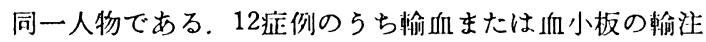

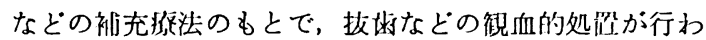
れているのは 6 例であった。

松尾ら ${ }^{22)}$ は数回に分制しての抜宵を行っているか，新

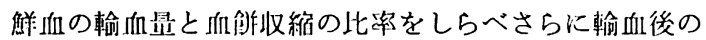
㭙間的推移をしらべて，最小量の輸注に努力している。 杉村ら ${ }^{25)}$ は的小板数を $30 \times 10^{3} / \mathrm{mm}^{3}$ 以上を目幅として


セル，止向灰にて局所を保览している，星山ら $\left.{ }^{26}\right)$ は術前 より免疫抑制㟫法を行いかつ血小板数 $10 \times 10^{4} / \mathrm{mm}^{3}$ の 上萃を目䧣に，PRP の輸拄を行いさらに局所の止血処





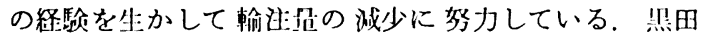
らつ) PRP の輸鿊を休重 $10 \mathrm{~kg}$ あたり 1 単位の割合で 行いやはり局所処浫の重要性を述へている，また，血管 強化作用，血小板第 3 图子作用莯物抗プラスミン剂など の补助的莯物の使用も推㨙している7).

一方占衍ら ${ }^{28)}$ は ITP の治療に使用されているプレド

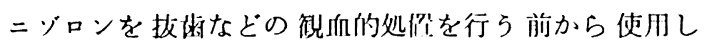
て止血管里を行っている。一力菜外国での赫告では,

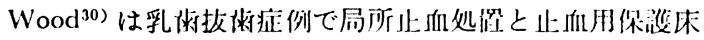
を装着したにもかかわらず後刡血が起こり，結局血小 板の愉注を行っている. Perkin ら ${ }^{31)}$ (拔懒㓣局所を microfibrillar collagen で被姼し epsilon aminocaproic acid（抗ブラスミン剂）の経口投与で拆榭を行い輸注は 極力さけるべきであると強調している。亦た Sugar ${ }^{32)}$ 


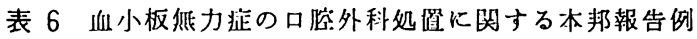

\begin{tabular}{|c|c|c|c|c|c|c|c|}
\hline 症例 & 報告者 & 報告作 & $\begin{array}{l}\text { 年邦 } \\
\text { (战) }\end{array}$ & 性 & 口井空外科処组 & 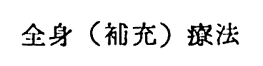 & 局所止血処㯰 \\
\hline 1 & 䄆 四ら & 1970 & 28 & 女 & $\frac{1}{7} \frac{1}{5 \sqrt{67}}$ 拔觜 ( 3 回) & 無 & スポンゼル・綎合 \\
\hline 2 & 松尼ら & 1970 & 20 & 男 & 拔幽・崡肉切除 & $\begin{array}{l}\text { 新站皿 } \\
\text { 血小板 }\end{array}$ & \\
\hline 3 & 金田 & 1970 & 8 & 男 & A 拔 槄 & 新解血 & $\begin{array}{l}\text { ゲラトロンピン } \\
\text { サージルハック }\end{array}$ \\
\hline 4 & 森 下ら & 1971 & 7 & 男 & 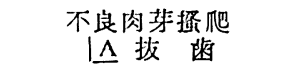 & 無 & スボンゼル・継合 \\
\hline 5 & 杉 村ら & 1975 & 14 & 多 & $\underline{5} \mid \overline{6 \mathrm{E}}$ 报 将 & 血小板 & オキシセル・保㒛林 \\
\hline 6 & 星 山ら & 1978 & 14 & 男 & 嗉胞摘出 & $\begin{array}{c}\text { シクロホスファ:ト } \\
\text { ブレドン゙ロン } \\
\text { PRP }\end{array}$ & $\begin{array}{l}\text { オシセル } \\
\text { 多孔性ラハー } \\
\text { 綎合 }\end{array}$ \\
\hline 7 & 長谷部ら & 1980 & 5 & 女 & 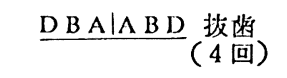 & PRP & $\begin{array}{l}\text { オキシセル・綎合 } \\
\text { シーネ }\end{array}$ \\
\hline 8 & 想 田ら & 1981 & 10 & 女 & $\underline{6} \mid \overline{\mathrm{E}}$ 拔 迷 & PRP & $\begin{array}{l}\text { スポソゼル・綎合 } \\
\text { サージカルハッック } \\
\text { シーネ }\end{array}$ \\
\hline 9 & & & 34 & 女 & 扳幽 (5本) & プドニソロン & \\
\hline 10 & 古 谷5 & 1982 & 31 & 女 &  & ブレドニゾロン & \\
\hline 11 & 本症 & 1984 & 46 & 女 & $\frac{54 \mid 67}{654 \mid 456}$ 拔崡（2回） & 無 & スポンゼル・䋖合 \\
\hline 12 & & & 41 & 女 & 18 拔 幽 & 無 & スボンゼル・䄳合 \\
\hline
\end{tabular}

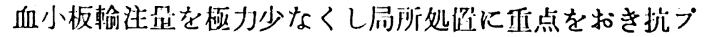
ラスミン剂の作用処院を行っている，われわれの症例 11，12は，何ら全身的初充痖沙を行らことなく，局所处

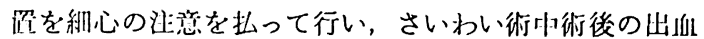
になやまされることなく経過した。

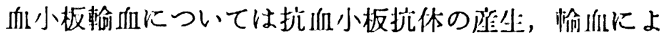
る副作用，輸血後服炎なと閌题点が多く，また榆血显の


ど䠐血的処谓が遂行されることが望ましいことは談家の 報告ど掞りである。

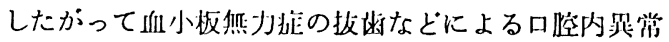

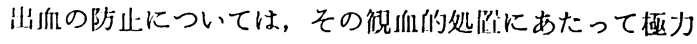

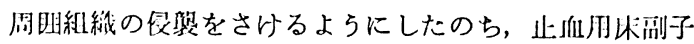
やサージカルパック，スポンゼルの俅用さらには䋖合な どで局所止血处涗を十分かつ碓非に行いさらに経口的に 抗プラスミン剂などの投卡により止血管理を行い，やむ を得ない湓合に限り，血小板輸很を效果的に必要热たけ を优仃すべきであると考える。

\section{結語}

われわれは邚沭の血小板然打症の抜米をそれぞれ $\frac{54 \mid 67}{654} \mid 456$ ， 多について行ったが局所止血处固のみで衍 中，術後の出血になやまされることなく治癒させること ができた 2 症例を報告した。

本部交の要旨は，第12回日本口管外科学会中国・四国 地方会（出零，炤和58年 5 月29日）に扣いて発表した。

\section{引用 文 献}

1) Glanzmann, E.: Hereditäre hamorrhagische thrombasthenic. Ein Bcitrag zur Pathologic der Blutplattechen. Jahrb Kinderheilk 88: 113-141 1918. 5) 上り引用。




资园顿柋（thrombocytoasthenia-Glanzmann

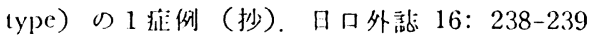
1970.

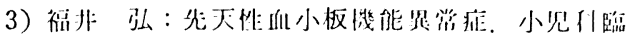
作 33: 5-15 1980 .

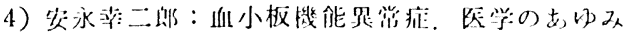
127: 83-90 1983.



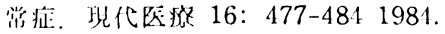

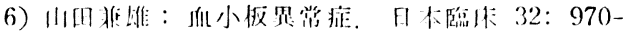
978 19\%1.

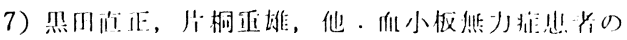

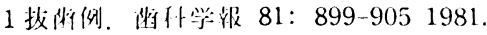

8) Weiss, H.J. and Kochwa, S. Studies of platelet function and proteins in 3 patients with Glanzmann's thrombasthenia. J Lab Clin Med 71: 153-165 1968.

9) Moser, K., Lechner, K., et al.: A hitherto not described enzyme defect in thrombasthenia: glutathionereductase deficiency. 'Thuomb Diath Hacmorh 19: 46-52 1968.

10) Karpatkin, S. and Weiss, H.J.. Deficiency of glutathione perioxidase associated with high levels of reduced glutathione in Glanzmann's thrombasthenia. New Engl J Med 287: 106210661972.

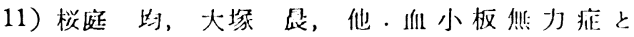

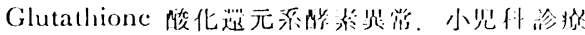
41: 215-221 1978.

12) Beutler, E.: Glanzmann's thrombasthenia and reduced glutathione. New Engl J Mid 287: 1094-1095 1972.

13) Caen, J.P., Castaldi, P.A., et al.: Congenital bleeding disorders with long bleeding time and normal platelet count. 1. Glanzmann's thrombasthenia (report of fifteen patients). Am J Mcd 41: 4-26 1966.

14) Nachman, R.L. and Marcus, A.J.. Immunological studies of proteins associated with subcellular fractions of thrombasthenic and afibrinogenemic platelets. $\mathrm{Br} \mathrm{J}$ Jlacmatol 15: 181-189 1968.

15) Booyse, F., Kisieleski, D., et al.. Possible thrombosthenin defect in Glanzmann's thrombasthenia. Blood 39: 377-381 1972.

16) Nurden, A.T. and Caen, J.P.: An abnormal platelet glycoprotein pattern in three cases of Glanzmann's thrombasthenia. Br J Haematol
28: 253-260 1974.

17) Phillips, D.R., Jenkins, ('.S. P., (t al.. Molecular dillerences of exposed surfiece proteins on thrombasthenic platelet plasma membrames. Nature 257: 599-600 1975.

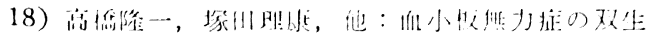

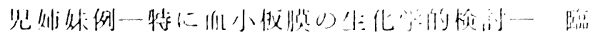
林III 该 18: 1137-11.12 1977.

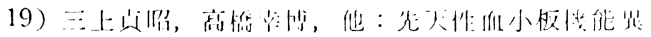

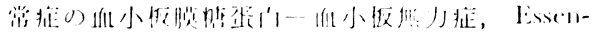
tial athrombia to to von Willebrand fyj

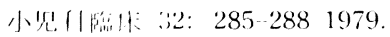

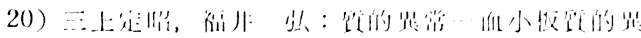

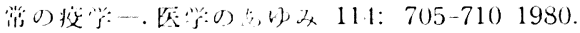

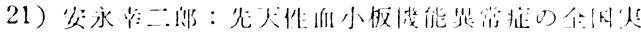

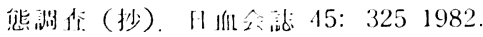

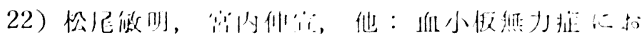

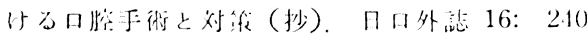
1970.

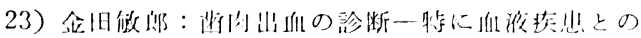



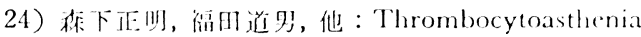

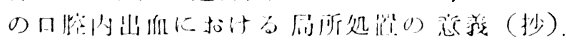
口(lit: 20: 3021971.

25) Sugimura, M., Yoshioka, A., el al.: Toolh extraction in a patient with Glanzmamus thrombasthenia. Int J Oral Surg 4: 130-135 1975.

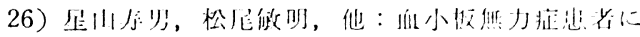

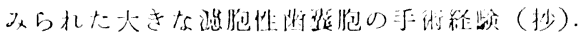
日口外䓌: 24：1307-1308 1978 .



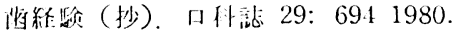

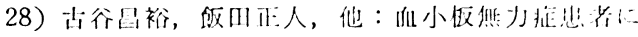

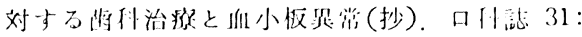
677-678 1982 .

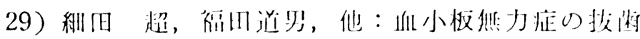
紑䠑（抄）。日口外乱 29: 2131983.

30) Wood, N.: Management of extractions in a case of Glanzmann's disease. l:r J Oral Surg 11: $152-1541973$.

31) Perkin, R.1., White, G.C., ct al.: Glanzmann's lhrombasthenia. Oral Surg 47: 36-39 1979.

32) Sugar, A.W.. The management of dental extractions in cases of thrombasthenia complicated by the development of isoantibodies to domor platelets. Oral Surg 48: 116-119 1979. 